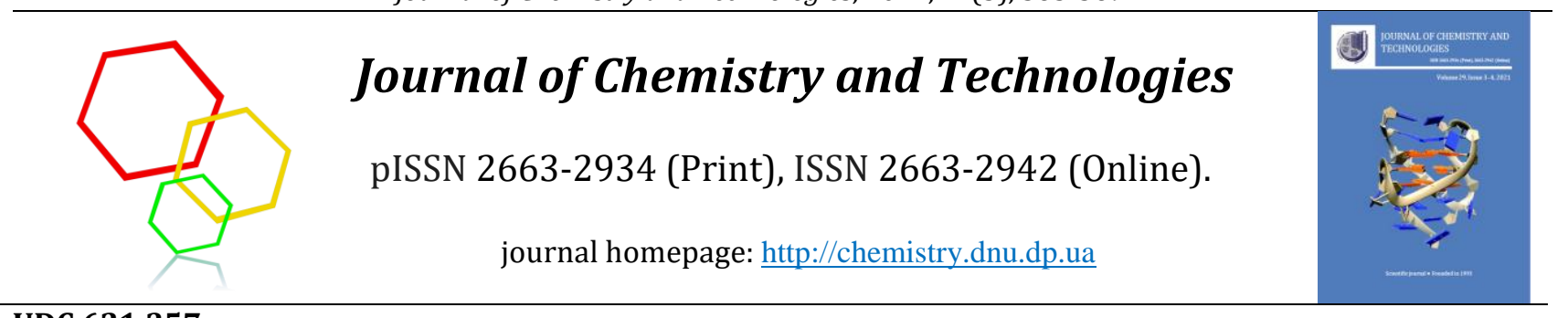

UDC 621.357

ELECTRODEPOSITED NANOSTRUCTURED POLYFUNCTIONAL TIN-BASED ELECTROCATALYST

\author{
Dmytro Yu. Ushchapovskyi*, Olga V. Linyucheva, Tetiana I. Motronyuk, Hlib Yu. Podvashetskyi \\ National Technical University of Ukraine «Igor Sikorsky Kyiv Polytechnic Institute», 37 Peremohy Av., 03056 Kyiv, Ukraine \\ Received 30 June 2021; accepted 21 September 2021; available online 27 October 2021
}

\begin{abstract}
The tin-based materials are widely used in sensor technology and also for the catalyst formation. The obtaining of materials with the highest specific surface area, which the volume-porous nano-ordered and structured material can provide, is an important task. In this investigation the electrodeposition of compact nanostructured cathodic tin deposits from sulfate solution with the additive OP-10 has been proposed. The presence of appropriate type of additives in the solution and significant deposition time caused the formation of nanostructured tin surface. It has been established that the highest productivity of $\mathrm{CO}_{2}$ electroreduction was achieved on electroformed tin electrodes whose deposition time was two hours. In the open type membrane cell at $\mathrm{CO}_{2}$ bubbling rate of $5 \mathrm{ml} / \mathrm{min}$ in a potentials range -1.5...-1.8 $\mathrm{V}$ the current efficiency varies between $11 \ldots 12.5 \%$. It has been shown that the maximal rate of sodium formate formation on the deposited nanostructured catalyst was observed at the electrode potential $-1.8 \mathrm{~V}$ and was twice higher than on polished tin.

Keywords: sulfate solution; tin-based catalyst, open type cell, sodium formate, current efficiency.
\end{abstract}

\title{
ЕЛЕКТРООСАДЖЕНИЙ НАНОСТРУКТУРОВАНИЙ БАГАТОФУНКЦІОНАЛЬНИЙ КАТАЛІЗАТОР НА ОСНОВІ ОЛОВА
}

\author{
Дмитро Ю. Ущаповський, Ольга В. Лінючева, Тетяна І. Мотронюк, \\ Гліб Ю. Підвашецький \\ Національний технічний університет України «Київський політехнічний інститут імені Ігоря Сікорського», \\ пр. Перемоги, 37, 03056 Київ, Україна
}

\begin{abstract}
Анотація
Матеріали на основі олова широко використовуються в сенсорній технології, а також для створення каталізатора. Отримання матеріалів 3 найбільшою питомою площею поверхні, яку може забезпечити об'ємно-пористий нано-впорядкований та структурований матеріал, є важливим завданням. У даній роботі запропоновано електроосадження компактних наноструктурованих катодних осадів олова 3 сульфатного розчину, що містить добавку ОП-10. Наявність відповідного типу добавок у розчині та значний час осадження спричинили утворення наноструктурованої поверхні олов'яних осадів. Встановлено, що найвища продуктивність електровідновлення $\mathrm{CO}_{2}$ досягнута на електроформованих олов'яних електродах, час осадження яких становив дві години. У мембранній комірці відкритого типу при швидкості барботування $\mathrm{CO}_{2} 5$ мл/хв у діапазоні потенціалів -1.5... -1.8 в (відносно Ag / AgCl) вихід за струмом коливається в межах $11 . .12 .5 \%$. Було показано, що максимальна швидкість утворення форміату натрію на електроосадженому наноструктурованому каталізаторі спостерігалася при електродному потенціалі -1.8 B (відносно Аg / AgCl) i є вдвічі вищою, ніж на полірованому олові.

Ключові слова: сульфатний розчин; каталізатор на основі олова, комірка відкритого типу, форміат натрію, вихід за струмом.
\end{abstract}

*Corresponding author: soltdim@gmail.com, tel.:+380442049737

(C) 2021 Oles Honchar Dnipro National University

doi: 10.15421/10.15421/jchemtech.v29i3.236134 


\title{
ЭЛЕКТРООСАЖДЕННЫЙ НАНОСТРУКТУРИРОВАНЫЙ ПОЛИФУНКЦИОНАЛЬНЫЙ ЭЛЕКТРОКАТАЛИЗАТОР НА ОСНОВЕ ОЛОВА
}

\author{
Дмитрий Ю. Ущаповский, Ольга В. Линючева, Татьяна И. Мотронюк,
} Глеб Ю. Подвашецький

Национальный технический университет Украины «Киевский политехнический институт имени Игоря Сикорского», пр. Победы, 37, 03056 Киев, Украина

\begin{abstract}
Материалы на основе олова широко используются в сенсорной технике, а также для создания катализаторов. Получение материалов с наибольшей удельной поверхностью, которую может обеспечить объемно-пористый наноупорядоченный и структурированный материал, является важной задачей. В данной статье предложено электроосаждение компактных наноструктурированных катодных осадков олова из сульфатного раствора, содержащего добавку ОП-10. Наличие соответствующего типа добавок в растворе и значительное время осаждения является причиной образования наноструктурированной поверхности оловянных осадков. Установлено, что самая высокая производительность электровосстановления CO2 достигнута на электроформируемых оловянных электродах, время осаждения которых составляло 2 часа. В мембранной ячейке открытого типа при скорости барботирования С02 5 мл / мин в диапазоне потенциалов -1.5 ... -1.8 В (относительно Ag / AgCl) выход по току колеблется в пределах 11 ... $12.5 \%$. Было показано, что максимальная скорость образования формиата натрия на электроосажденном наноструктурированном катализаторе наблюдалась при электродном потенциале -1.8 В (относительно Аg / AgCl) и была вдвое выше, чем на полированном олове.

Ключевые слова: сульфатный раствор, катализатор на основе олова, ячейка открытого типа, формиат натрия, выход по току.
\end{abstract}

\section{Introduction}

The tin-based materials are widely used in sensor technology and also for the catalyst formation [1-3]. In metallic form tin is used as a catalyst for carbon dioxide electroreduction due to high hydrogen overvoltage [4-6]. The electrochemical reduction of $\mathrm{CO}_{2}$ to the formic acid or in the alkaline medium to formates effective liquid fuel - is of major concern [7-11].

One of the most significant parameters which determines the expediency of catalyst application except selectivity is the rate of the target product formation. The rate or productivity of the process, as it is known, rises with the increase in the specific surface area of the catalyst. Catalysts with bulk porous nanoscale structured surface have the highest catalytic activity [12-16].

Electrodeposition of metal on the constant or pulse current is one of the processes of metal catalysts formation. This process, in particular, is used for obtaining tin-based catalytic electrode materials with a nanoscale structure [10;13-19].

As already noted, the obtaining of materials with the highest specific surface area, which the volume-porous nano-ordered and structured material can provide, is an important task as well. Such structures are also called capillary porous surfaces (CPS). Production of CPS by copper electrodeposition was described in the works of M. I. Donchenko and A. N. Aleksandrovsky, where the achievement of the necessary properties of the deposition was realized by veering of the working current density, the solution composition and a certain kind of additives [2022]. In the present work, the approach that was previously proposed and used for the electrodeposition of copper CPS, is applied for the preparation of tin nanostructured catalytic materials.

\section{Experimental Section}

The surface morphology of tin deposits was examined by ZEISS EVO 50XVP scanning electron microscope equipped with an INCA450 energy dispersive analyzer and INCAPent-FETx3 detector and the HKL CHANNEL-5 system for the diffraction of reflected electrons from OXFORD.

The electrodeposition of tin catalysts was carried out in solutions containing $(\mathrm{g} / \mathrm{l})$ : №1 $\mathrm{SnSO}_{4}-40, \mathrm{H}_{2} \mathrm{SO}_{4}-70$, gelatin - 2; №2 $\mathrm{SnSO}_{4}-$ $40, \mathrm{H}_{2} \mathrm{SO}_{4}-70$, gelatin - 2, phenol - 30; №3 $\mathrm{SnSO}_{4}$ - 40; $\mathrm{H}_{2} \mathrm{SO}_{4}-70$; gelatin - 2; additive OP-10 - 1 .

Tin catalyst electrodeposition, voltammetric and chronopotentiometric measurements were taken in a three-electrode cell with a PI-50-1 potentiostat. Cathode polarization curves were obtained at a scan rate of $10 \mathrm{mV} / \mathrm{s}$. Current and potential values were registered with a Hantek DSO 6022be USB oscilloscope. Potentials were measured relative to a saturated silver-chloride reference electrode $(\mathrm{Ag} / \mathrm{AgCl})$.

Electroreduction of $\mathrm{CO}_{2}$ was carried out in potentiostatic conditions using an open type two compartment membrane cell with cation exchange Nafion 117. An aqueous solution of $0.1 \mathrm{M} \mathrm{NaHCO}_{3} \mathrm{pH} 6.8$ was used as a catholyte, $0.5 \mathrm{M} \mathrm{NaHCO}_{3}$ was used as an anolyte. The acidity of the catholyte was regulated by addition of minute quantity of saturated sulfuric acid. As a cathode, rectangular plates of copper foil on 
Journal of Chemistry and Technologies, 2021, 29(3), 363-369

which a tin catalyst was deposited were used, the cathode working area was $3.5 \mathrm{~cm}^{2}$. A stainless steel plate was used as an anode. A catholyte was saturated with $\mathrm{CO}_{2}$ by bubbling for one hour before electrolysis. $\mathrm{CO}_{2}$ gas at a flow rate of $5 \mathrm{ml} \cdot \mathrm{min}^{-1}$ was supplied continuously to the catholyte using glass capillary throughout the electroreduction experiments. The Kipp apparatus with a Drexel flask filled with distilled water for gas purification was used as a source of $\mathrm{CO}_{2}$. The amount of formate and current efficiency (FE) were determined by permanganometric titration using the following method. In a conical flask to $5 \mathrm{ml}$ of a sample of a formate containing solution a saturated sodium carbonate solution was added to $\mathrm{pH} 11$ and then $5 \mathrm{ml}$ of $0.1 \mathrm{M} \mathrm{KMnO}_{4}$ was added. Then, the resulting mixture was heated up to $50{ }^{\circ} \mathrm{C}$ to accelerate the oxidation reaction, after 5 minutes $2 \mathrm{ml}$ of $1.5 \mathrm{M} \mathrm{H}_{2} \mathrm{SO}_{4}$ was added to create the acidic medium. After which the remainder of the permanganate was titrated with $0.1 \mathrm{M} \mathrm{H}_{2} \mathrm{C}_{2} \mathrm{O}_{4}$. The amount of formate was calculated from the difference in the volumes of $\mathrm{H}_{2} \mathrm{C}_{2} \mathrm{O}_{4}$, which was consumed for the titration of the sample and $5 \mathrm{ml}$ of the original $0.1 \mathrm{M} \mathrm{KMnO}_{4}$. All the solutions were prepared from $\mathrm{CP}$ or analytical grade reagents (Khimlaborreaktiv) in distilled water. Fixed channels were used for the preparation of standard solutions $\mathrm{H}_{2} \mathrm{C}_{2} \mathrm{O}_{4}$ and $\mathrm{KMnO}_{4}$.

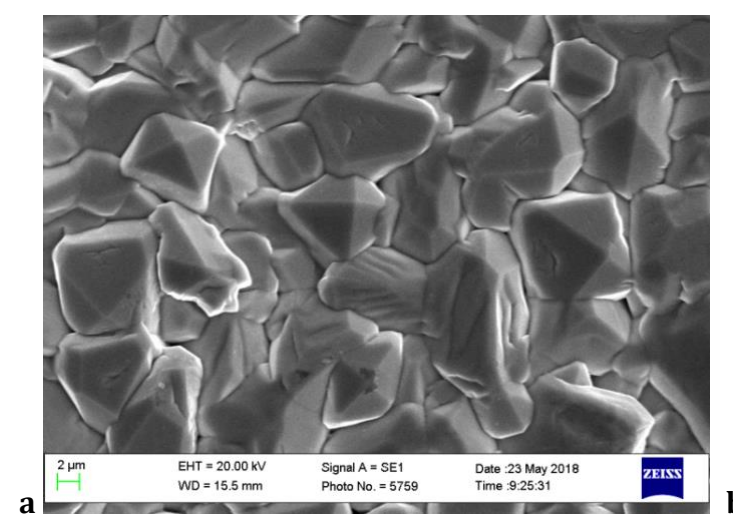

\section{Results and its discussion}

Tin catalysts electrodeposition. As a result of the electrodeposition of tin from sulphate electrolytes with various types of organic additives, compact deposits without vickers and dendrites were obtained, and the SEM images of the surface are shown in Fig.1.

As can be seen from Fig. 1.a, macrocrystalline deposits with a smoothed surface are obtained from an electrolyte containing phenol and gelatin. Externally, such coatings are semi-bright. A velvet like deposits were obtained from the electrolyte containing gelatin and OP-10, the surface microstructures of which are shown in Fig. 1 b, c. As it can be seen (Fig. 1, b, c), the crystals have a more pronounced pyramidal shape than in Fig. 1 a, with the same thickness. In addition, on the surface of deposits Fig. 1 b, there are nanoscale (about $100 \mathrm{~nm}$ thick) grooves. With an increase in deposition time (Fig. 1c), the deposit structure changes: the number of pyramidal crystals decreases, but they become more elongated (needle-shaped), in addition, nanoscale grooves are smoothed. Externally, deposits obtained from electrolytes №. 2, 3 (Fig. 1b, c) are compact. The intensity of their color depends on the angle of the sun's rays. In addition, deposits are well wetted and absorbed water, which indicates their capillary properties.
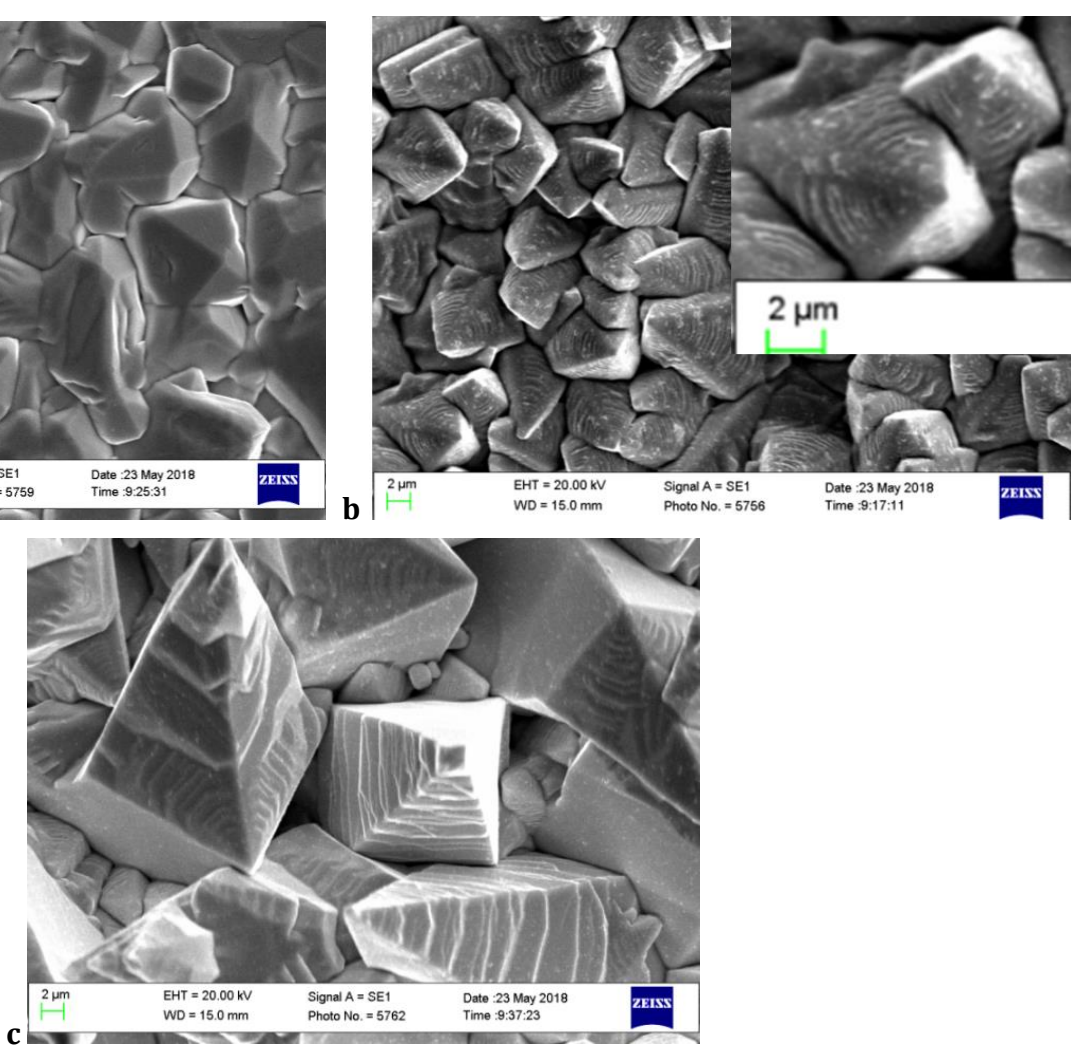

Fig. 1. SEM-image of Sn deposits obtained from sulfate electrolytes: a - №2; b, c - №3. Deposition time, hours: a - 1; b - 2; c-4. Current density, A/dm ${ }^{2}: a-1 ; b, c-0.5$. 
The OP-10 additive is a wetting agent that has the gross formula $\mathrm{O}\left(\mathrm{CH}_{2}-\mathrm{CH}_{2}-\mathrm{O}\right)_{10} \mathrm{CH}_{2}-\mathrm{CH}_{2}-\mathrm{OH}$ and is used in this work. OP-10 belongs to the class of additives that, for the first time, was proposed by M.I. Donchenko and A.N. Aleksandrovsky for the deposition of copper capillary-porous coatings. According to their works $[20 ; 21]$, the necessary conditions for electrodeposition of coatings with high capillary properties and a developed microstructured surface are: the presence of additives of the appropriate type in the solution, diffusion limitations during metal electrodeposition, significant (several hours) deposition time.

To explain the effect of additives on the deposit structure and the cathodic tin deposition process, the current-voltage curves were obtained (Fig. 2).

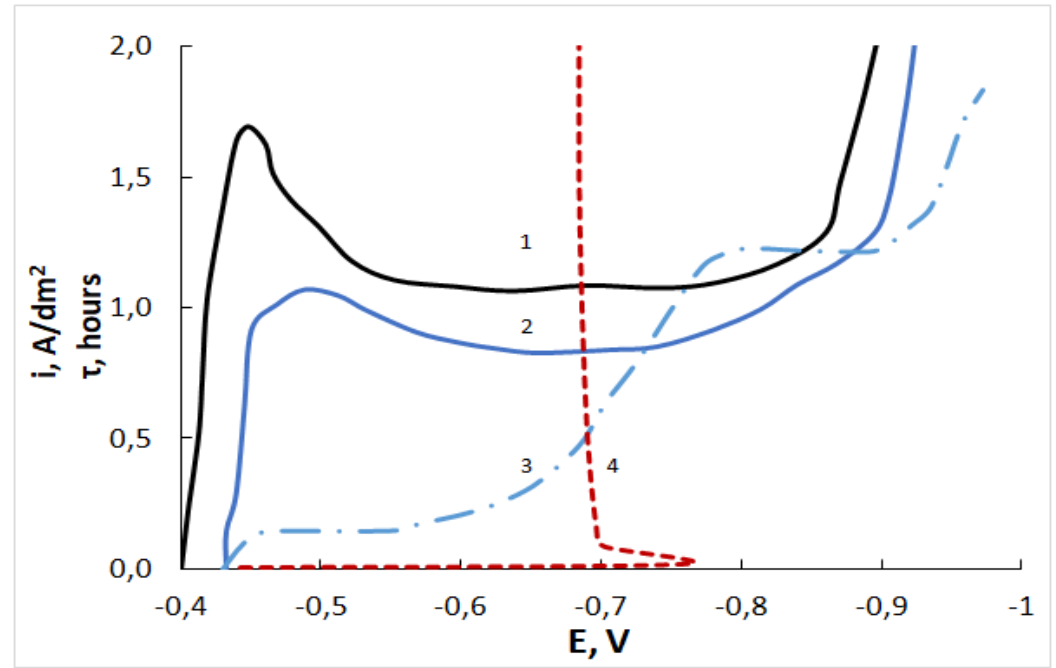

Fig.2. Cathodic potentiodynamic $(1-3)$ and chronopotentiometric at $0,5 \mathrm{~A} / \mathrm{dm}^{2}(4)$ polarization curves of $\mathrm{Sn}$ electrodeposition in sulfate electrolytes: 1 - №1; 2 - №2; 3, 4 - №3

From the potentiodynamic cathodic polarization curves, it can be seen that the electrodeposition of tin from solution with gelatin (Fig. 2, curve 1) in the current density range up to $1 \mathrm{~A} / \mathrm{dm}^{2}$ proceeds with a characteristic low polarization. Additional introduction of phenol into the solution (Fig. 2 curve 2) leads to a shift of the equilibrium potential to negative values and a decrease in the value of the limiting current density, apparently due to phenol adsorption. This is consistent with [15;23;24].

With the introduction of OP-10 into the solution, a limiting current appears in the region of low current densities (about $0.1 \mathrm{~A} / \mathrm{dm}^{2}$ ), which associated with the adsorption of the additive. The next wave of the curve (current density range of $0.1 \ldots 1.2 \mathrm{~A} / \mathrm{dm}^{2}$ ) and the second limited current density with a further transition to the hydrogen evolution process are observed after the first limiting current. During the electrodeposition of tin from a solution №3 at a constant current density of $0.5 \mathrm{~A} / \mathrm{dm}^{2}$ (Fig. 2, curve 4), the magnitude of the stationary potential, which was established after 0.17 hours, corresponded to the polarization curve (Fig. 2, curve 3). This can be explained by the fact that at the electrodeposition process the working surface area remains almost unchanged. Thus, during the electrodeposition of tin from the solution with OP-10, the current is distributed mainly along the tops of the pyramid crystallites, on which the deposit grows, mainly in the normal direction to the substrate, which is consistent with the nature of the structure modification (Fig. 1 b, c). Also, by the optical method, focusing the microscope on the tops of the crystallites and in the hollows (with an increase of x40000) the following was established. With the estimated deposit thickness $27.5 \mu \mathrm{m}$ (Fig. 1b), the height of the crystallites is $15 \mu \mathrm{m}$; with a calculated deposit thickness $55 \mu \mathrm{m}$ (Fig. 1c), the crystallite height is $21 \mu \mathrm{m}$. All the above facts are consistent with [20-22] and explain the formation of structured dendritic capillary-porous deposits.

Evaluation of catalytic properties of the obtained materials. Tin, as a metal with significant hydrogen overpotential, is used as a catalyst for the hydrogenation of organic compounds, as well as for the reduction of carbon dioxide to formic acid or formates according to the total reaction [6; 14]:

$$
\mathrm{CO}_{2}+\mathrm{HCO}_{3}^{-}+2 \mathrm{e}=\mathrm{HCOO}^{-}+\mathrm{CO}_{3}^{2-} .
$$

In particular, it was shown in [6] that the surface structure of a tin catalyst significantly 
affects the current efficiency of potassium formate. In addition, in a number of works [4-8; $14]$, it was shown that $\mathrm{pH}$, cathode potential, type of indifferent cation have a significant effect on current efficiency of formate formation. Also, it was shown that in $0.1 \mathrm{KHCO}_{3}$, the maximum formate yield is observed at $\mathrm{pH} 6,85$ and a potential of about $-1.48 \mathrm{~V}$ (NHE) or $-1.7 \mathrm{~V}$ (vs. $\mathrm{Ag} / \mathrm{AgCl})[4]$.

For a comparative evaluation of the catalytic activity of tin-based materials, obtained in this work, it was proposed to use $0.1 \mathrm{M} \mathrm{NaHCO}_{3}$ [14] with an initial pH 6.8.

The potentiostatic current-voltage curves, which were obtained on the studied materials, indicate the following (Fig. 3.).

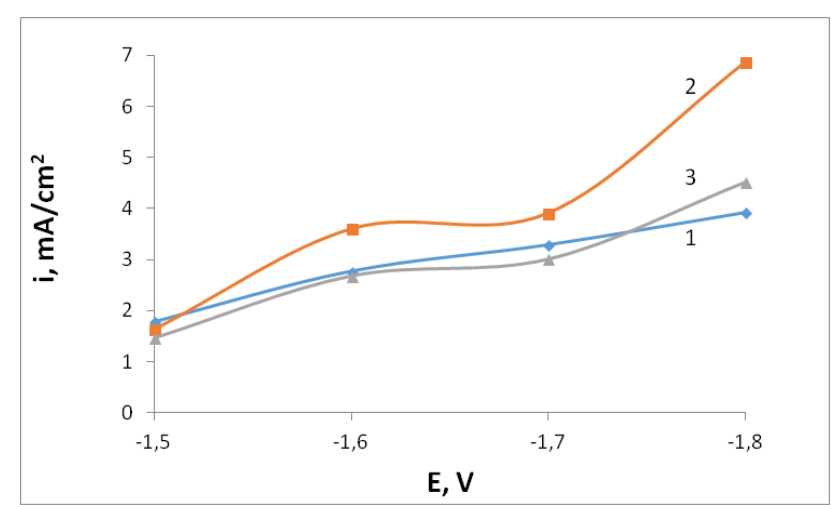

Fig.3. Potentiostatic current-voltage curves in 0,1 M $\mathrm{NaHCO}_{3}$ on Sn electrodes: 1 - polished $\mathrm{Sn} ; 2$ electrodeposited in sulfate solution №3, deposition time 2 hours; 3 - electrodeposited in sulfate solution №3, deposition time 4 hours.

On the polished tin electrode and on the electrode with the surface structure shown in (Fig. 1 c), the current density values in the potential range of $-1.5 \ldots-1.8 \mathrm{~V}$ are approximately the same. On the electrode with the structure (Fig. $1 \mathrm{~b}$ ), the current density in the potential range of $-1.6 \ldots-1.8 \mathrm{~V}$ is $20 \ldots 40 \%$ higher than on the other tested samples. This may indicate that the electrode material (Fig. 1 b) has a greater true working surface area than polished tin and the material (Fig. $1 \mathrm{c}$ ).

The maximum current or Faradaic efficiency (FE) of formate obtained on the studied electrode materials does not exceed $12.5 \%$ (Fig. 4). This may be due to the nature of the cation [8], low volumetric flow rate of $\mathrm{CO}_{2}(5 \mathrm{ml} / \mathrm{min})$, and cell design features (the cell is not hermetic).

As follows from Fig. 4, curves 1, 3, the maximum $\mathrm{FE}$ for polished tin and tin with the structure (Fig. 1c) is observed at the potential of $1.7 \mathrm{~V}$ (vs. $\mathrm{Ag} / \mathrm{AgCl}$ ), which is consistent with the data obtained in a solution of $0,1 \mathrm{M} \mathrm{KHCO}_{3}$ [4-6].

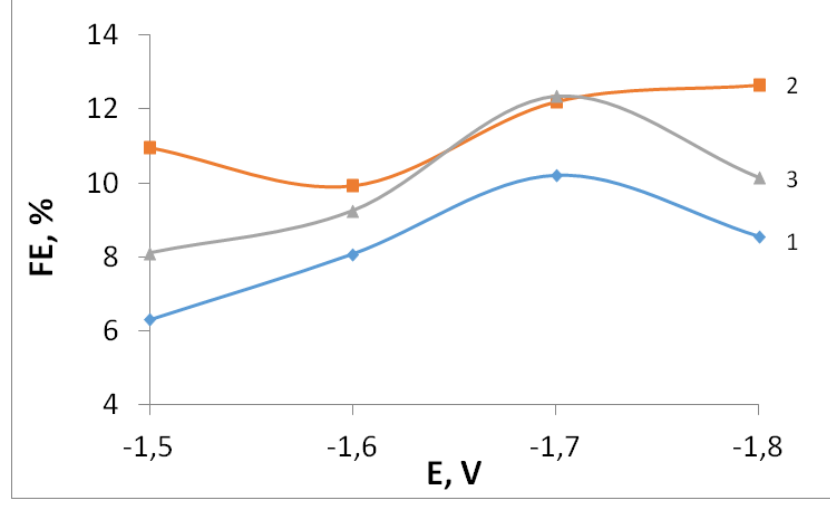

Fig.4. FE vs electrode potential dependences in 0,1 $\mathrm{M}$ $\mathrm{NaHCO}_{3}$ on Sn electrodes: 1 - polished Sn; 2 electrodeposited in sulfate solution №3, deposition time 2 hours; 3 - electrodeposited in sulfate solution №3, deposition time 4 hours

The Faradaic efficiency on the electrode with the surface structure (Fig. $1 \mathrm{c}$ ) in the range of potentials $-1.5 \ldots-1.8 \mathrm{~V}$ is $20 \%$ higher than on polished tin. On the electrode with the surface structure (Fig.1 b), the Faradaic efficiency is the same as on the electrode with the surface structure of Fig. $1 \mathrm{c}$, in the range of potentials $-1.6 \ldots$ -1.7 V. However, on the electrode with the surface structure (Fig. 1b), a decrease in the FE at potentials of -1.5 and $-1.8 \mathrm{~V}$ is not observed, at these potentials the Faradaic efficiency is 1.3...1.8 times higher than at other studied electrodes.

In addition to the current or Faradaic efficiency, an important technological parameter is the rate of substance formation, which gives an idea of the degree of conversion of the original substance $\mathrm{CO} 2$ into a product - formate (Fig. 5).

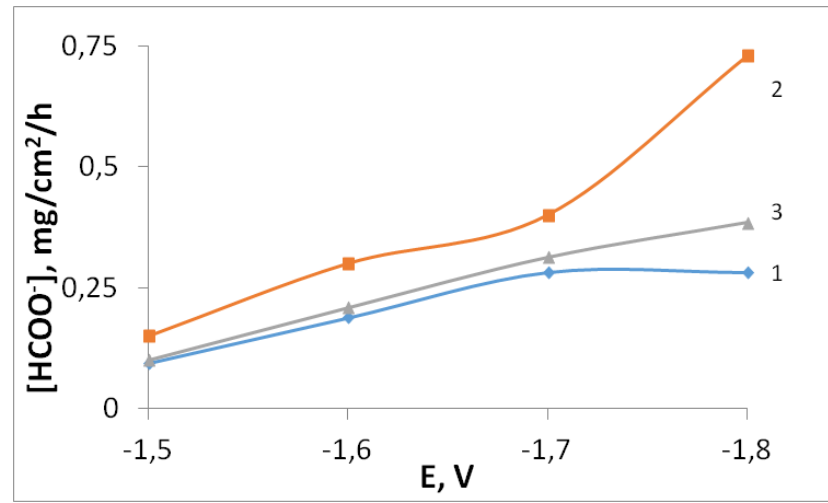

Fig.5. Rate of formate formation vs electrode potential dependences in 0,1 $\mathrm{M} \mathrm{NaHCO}_{3}$ on Sn electrodes: 1 polished Sn; $\mathbf{2}$ - Sn electrodeposited in sulfate solution №3, deposition time 2 hours; 3 - Sn electrodeposited in sulfate solution №3, deposition time 4 hours.

As it can be seen from Fig. 5, the rates of formate formation on a polished tin electrode and on an electrode with a surface structure (Fig. 1c) are almost the same. In the range of potentials $1.5 \ldots-1.7 \mathrm{~V}$, the rate of formate formation on the electrode with a surface structure (Fig. 1 b) is 25 
... $30 \%$ higher than on the other studied samples of electrodes.

Thus, the electrode material obtained in the present work with the surface structure (Fig. 1b) has the highest catalytic efficiency with respect to reaction (1) at a potential of $-1.8 \mathrm{~V}$ ( $\mathrm{vs} . \mathrm{Ag} / \mathrm{AgCl}$ ). At the same time, the rate of formate formation is 2...2.5 times higher than on other test samples. This can be explained by the peculiarities of the electrode material structure, the pyramidal crystallites of which have nanoscale grooves on their surface. With excessively long electrodeposition, the structure is modified (Fig. $1 \mathrm{c})$. The number of crystallites decreases, their size increases, and the surface becomes smoother, while the catalytic activity decreases.

\section{Conclusion}

Electrodeposition of tin-based electrode material with a nanostructured highly developed surface from a sulphate solution with the addition of organic additives has been proposed. It has been shown that the structure of tin deposits obtained from the proposed electrolyte has nanoscale grooves.

The current efficiency of formate on electrodes with obtained developed structure is 1.3 ... 1.8 times higher than that of polished tin. It has been established that the highest rate of formate formation $\left(0.75 \mathrm{mg} / \mathrm{cm}^{2} / \mathrm{h}\right)$ is observed on nanostructured tin electrodes with an electrodeposition duration of 2 hours at the potential of $-1.8 \mathrm{~V}$ (vs. $\mathrm{Ag} / \mathrm{AgCl}$ ).

\section{References}

[1] Linyucheva, O., Gomelya, M., Linyuchev, A., Havrylova, O., Doronkina, L. (2019). Environmental monitoring of gas emissions into the air with a sensory block. Materialstoday: Proceedings, 6(2), 211-217.

doi.org/10.1016/j.matpr.2018.10.096

[2] Sun, Z., Ma, T., Tao, H., Fan, Q., Han, B. (2017). Fundamentals and challenges of electrochemical $\mathrm{CO}_{2}$ reduction using two-dimensional Materials. Chem, 3(4), 560-587. doi.org/10.1016/i.chempr.2017.09.009

[3] Velmathi, G., Mohanb, S., Henry, R., (2016). Analysis and review of tin oxide-based chemoresistive gas sensor. IETE Technical Review, 33(3), 323-331. doi.org/10.1016/j.chempr.2017.09.009

[4] Hori Y., Wakebe, H., Tsukamoto, T., Koga, O. (1994). Electrocatalytic process of $\mathrm{CO}$ selectivity in electrochemical reduction of $\mathrm{CO}_{2}$ at metal electrodes in aqueous media. Electrochimica Acta, 39(11-12), 1833 1839. doi.org/10.1016/0013-4686(94)85172-7

[5] Hori, Y., Kikuchi, K., Suzuki, S., (1985). Production of $\mathrm{CO}$ and $\mathrm{CH}_{4}$ in electrochemical reduction of $\mathrm{CO}_{2}$ at metal electrodes in aqueous hydrogen carbonate solution. Chemistry letters, 14(11), 1695-1698. doi.org/10.1246/cl.1985.1695

[6] Zhao, C., Wang, J., (2016). Electrochemical reduction of $\mathrm{CO}_{2}$ to formate in aqueous solution using electro- deposited Sn catalysts. Chemical Engineering Journal, 293, 161-170. doi.org/10.1016/i.cej.2016.02.084

[7] Surya Prakash, G.K., Viva, F.A., Olah, G.A., (2013). Electrochemical reduction of $\mathrm{CO}_{2}$ over $\mathrm{Sn}$ Nafion ${ }^{\circledR}$ coated electrode for a fuel-cell-like device. Journal of Power Sources, 223, 68-73. doi.org/10.1016/j.jpowsour.2012.09.036

[8] Qiao, J., Liu, Y., Zhang, J., (2016). Electrochemical reduction of carbon dioxide: Fundamentals and Technologies. London, UK: CRC Press. doi/10.1201/b20177-4

[9] Zheng, X., Han, J., Fu, Y., Deng, Y., Liu, Y., Yang, Y., Wang, T., Zhang L., (2018) Highly efficient $\mathrm{CO}_{2}$ reduction on ordered porous $\mathrm{Cu}$ electrode derived from $\mathrm{Cu}_{2} \mathrm{O}$ inverse opals. Nano Energy, 48, 93-100 doi.org/10.1016/j.nanoen.2018.03.023

[10] Li, F.W., Chen, L., Xue, M.Q., Williams, T., Zhang, Y., MacFarlane, D.R., and Zhang, J. (2017). Towards a better $\mathrm{Sn}$ : efficient electrocatalytic reduction of $\mathrm{CO}_{2}$ to formate by $\mathrm{Sn} / \mathrm{SnS}_{2}$ derived from $\mathrm{SnS}_{2}$ nanosheets. Nano Energy, 31, 270-277. doi.org/10.1016/i.nanoen.2016.11.004

[11] Wang, H.X., Chen, Y.B., Hou, X.L., Ma, C.Y., and Tan, T.W. (2016). Nitrogen-doped graphenes as efficient electrocatalysts for the selective reduction of carbon dioxide to formate in queous solution. Green. Chem., 18, 3250 - 3256. doi.org/10.1039/C6GC00410E

[12] Taberna, P.L., Mitra, S., Poizot, P., Simon, P., Tarascon J.M. (2006). High-rate capabilities $\mathrm{Fe}_{3} \mathrm{O}_{4}$-based $\mathrm{Cu}$ nanoarchitectured electrodes for Lithium-ion Battery Applications. Nature Materials, 5(7), 567 - 573. DOI: $10.1038 /$ nmat 1672

[13] Li, F.W., Chen, L., Knowles, G.P., MacFarlane, D.R., and Zhang, J. (2017). Hierarchical mesoporous $\mathrm{SnO}_{2}$ nanosheets on carbon cloth: a robust and flexible electrocatalyst for $\mathrm{CO}_{2}$ reduction with high efficiency and selectivity. Angew. Chem. Int. Ed., 56, 505-509. doi.org/10.1002/anie.201608279

[14] Zhang, S., Kang, P., Meyer, T.J., (2014). Nanostructured tin catalysts for selective electrochemical reduction of carbon dioxide to formate. J. Am. Chem. Soc., 136(5), 1734 - 1737. doi.org/10.1021/ja4113885

[15] Uschapovskyi D.Yu., Linyucheva O.V., Redko R.M., Doronkina L.A. (2020). Electrodeposition of threedimensional structured cadmium doped tin coatings. Promising Materials and Processes in Applied Electrochemistry. In V. Z. Barsukov (Ed.). Kyiv, Ukraine: KNUTD. https://er.knutd.edu.ua/bitstream/123456789/18610 11/Promising 2019 P067-075.pdf

[16] Choi, S.Y., Jeong, S.K., Kim, H.J., Park, K.T. (2016). Electrocatalytic reduction of carbon dioxide on Sn$\mathrm{Pb}$ alloy electrodes. Journal of Climate Change Research, 7(3), 231-236. doi.org/10.15531/KSCCR.2016.7.3.231

[17] Sujat, S., Skinnb, B., Radhakrishnan, R., McLain, L., Brushett, F.R. (2017). Electrodeposited $\mathrm{Cu}$ Film Catalysts for Electrochemical $\mathrm{CO}_{2}$ Reduction to Ethylene. ECS Transactions, 77 (11), 933-946. DOI: $10.1149 / 07711.0933$ ecst

[18] Mackay, D.T., Janish, M.T., Sahaym, U., Kotula, P.G., Jungjohann, K.L., Carter, C.B., Norton M.G. (2014). Template-free electrochemical synthesis of tin nanostructures. J. Mater Sci, 49, 1476-1483. doi.org/ $\underline{10.1007 / s 10853-013-7917-1}$

[19] Burek, M.J., Budimanb, A.S., Nobumichi, Z.J., Kunzc, T.M., Jina S., Hand, S.M.J., Leea G., Zamecnika, C., Tsuia, T.Y. (2011). Fabrication, microstructure, and 
mechanical properties of tin nanostructures. Materials Science and Engineering: A, 528(18), 5822-5832. doi.org/10.1016/i.msea.2011.04.019

[20] Aleksandrovskiy, A.N., Donchenko, M.I., Bondarenko, L.I., (1990). Features of cathodic deposition of capillary-porous coatings from sulfuric acid electrolyte of copper plating with the addition of surfactants. Khim. i neftyanoye mashinostroyeniye, 12, 31-32. (in Russian).

[21] Aleksandrovskiy, A.N., Donchenko, M.I., Bondarenko, L.I., Klimkin, Ye.V., (1992). Electrodeposition of capillary-porous coatings. Izvestiya vysshikh uchebnykh zavedeniy. 36(1), 77 - 79. (in Russian).
[22] Uschapovskyi, D.Yu., Linyucheva, O.V., Donchenko, M.I., Byk, M.V., Tsymbalyuk, A.S. (2016). Method of controlling the morphology of cathode deposit by determining electrochemical resistance for copper electrodeposition process. Res. Bulletin NTU KPI, 2, 114-121. doi: 10.20535/1810-0546.2016.2.60951

[23] Walsh, F.C., Low, C.T.J. (2016) A review of developments in the electrodeposition of tin. Surface and Coatings Technology, 288, 79-94. doi.org/10.1016/j.surfcoat.2015.12.081

[24] Kudryavtsev, N.T., (1979). Electrochemical metal coatings. Moscow, USSR: Khimiya. 